\title{
Student choices of choosing colleges and course of study in Penang
}

\author{
Kristina Khoo', Teoh Kok Ban², Chow Yong Neng3 ${ }^{3}$, Beh Kok Hooi ${ }^{4}$, Chong Yee Joan ${ }^{5}$ \\ ${ }^{1}$ Editor, Han Chiang College, Penang, Malaysia (kristinakhoo@hju.edu.my) \\ ${ }^{2}$ Lecturer, Han Chiang College, Penang, Malaysia (derickteoh@hju.edu.my) \\ ${ }^{3}$ Chief executive, Han Chiang College, Penang, Malaysia (chowyn@hju.edu.my) \\ ${ }^{4}$ Vice principal, Han Chiang College, Penang, Malaysia (khbeh@hju.edu.my) \\ ${ }^{5}$ Lecturer, Han Chiang College, Penang, Malaysia (chongyj@hju.edu.my)
}

Received 22 June, 2015

Copyright (C) 2014 (Kristina Khoo, Teoh Kok Ban, Chow Yong Neng, Beh Kok Hooi, Chong Yee Joan). This is an open access article distributed under the Creative Commons Attribution-NonCommercial-NoDerivatives 4.0 International License., which allowing others to download this work and share them with others as long as they credit us, but they can't change them in any way or use them commercially. In accordance of the Creative Commons Attribution License all Copyrights (C) 2014 are reserved for ABC Research Alert and the owner of the intellectual property (Kristina Khoo, Teoh Kok Ban, Chow Yong Neng, Beh Kok Hooi, Chong Yee Joan). All Copyright (C) 2014 are guarded by law and by $A B C$ Research Alert as a guardian.

\begin{abstract}
A preliminary survey is conducted to identify student choices of choosing colleges and course of study in Penang. The methodology used in the study is convenience sampling, and feedback from the survey indicates that parents are the most important or influential people, apart from friends, relatives and counsellors. Educational marketers should utilise the preliminary findings of the study to produce appropriate marketing strategies to promote their products and services.
\end{abstract}

Keywords

Students, parents, college, course of study

\section{Introduction}

Today's private higher education market in Malaysia does not only cater to the rich and affluent community as it also provides opportunities for further studies to local and international students. Malaysia's private higher education helps to shoulder the costs of higher education and absorbs high enrolment demands due to the limited places offered in public universities, especially with the ever increasing number of qualified high school leavers. Students who aim to further their studies, but are held back due to financial restraints or fail to meet the requirements of public universities, will have to opt for private universities or colleges. 
Hence, the demand for private education in Malaysia will continue to rise, creating a healthy competition among private higher institutions.

To survive in this highly competitive industry, private colleges / university colleges are offering a wide range of programmes (both academic and skill development), financial aids and other options to attract prospective students. For many students and parents, private higher education means a substantial investment in monetary and temporal terms. With the current financial situation in Malaysia and the erosion in the value of the Malaysian Ringgit against the US dollar, majority of parents are becoming more selective when it comes to choosing the right educational institution for their children. In order for private colleges to effectively publicise their services, educational marketers need to understand their student markets. Therefore, educational marketers and relevant parties must attempt to ask themselves the most fundamental questions; Why do students select a particular college or university from the large number of alternatives and who is the most influential / important person when choosing a college and course of study?

\section{Research Objectives}

This study is conducted to identify external and internal sources associated with student choices for choosing colleges and course of study in Penang. The study is based on the following objectives: (i) to identify persons that influence students when they choose their colleges and course of study; (ii) to identify attributes or characteristics of the colleges that influence students' opinions and perceptions on private college choices; (iii) to identify reasons and concerns of students when deciding to further their studies.

\section{Literature Review}

This study is about the sources associated with student choices for choosing colleges and course of study. The decision whether to continue or not to continue with post-secondary education and the choice to choose the "right" institutions and course of study are two critical decisions to be undertaken by students. For those students who wish to further their studies to university level, the selection process probably assumes high priority. Many factors and conditions need to be considered because these factors would probably affect the final decision. Identifying those sources and information that might be considered by students is the main objective of the study.

Developing a list of factors considered important to students would be the main goals of educational marketers and students themselves. Important factors considered during the selection process include programmes offered, reputation and image of the college, course fees, financial aids, influence from family members and peers, and facilities. A study by Samsinar Md. Sidin, Siti Rahayu Hussin and Tan (2003) surveyed 210 respondents from the Klang Valley to identify factors influencing the college choice decision of undergraduate students. The results confirmed that when students are selecting colleges, they depend on several criteria which include academic quality, facilities, college environment and personal characteristics.

\section{Data Analysis}

Convenience sampling is used as the sampling method. Statistical Package for Social Sciences (SPSS) software is used in the analysis of primary data. Only descriptive statistics are used to analyse the data collected including cross tabulation, frequencies, percentages and means. The 
usage of descriptive statistics is to describe, summarise and present a set of data, in order to simplify the large amount of data in a more sensible way (Berenson, Levine and Krehbiel, 2006).

\section{Sample}

The sample of the study comprises college students and non-college students from Penang. The study is a non-experimental cross-sectional survey design involving college students and non-college students in Penang. The questionnaire is designed to collect information regarding each of the research objectives being studied. Questionnaires were distributed to college students personally and partially via the web. A total of 380 questionnaires were completed and returned. After the data were collected, each questionnaire was coded and scores were entered into the Statistical Software for Social Sciences (SPSS) for Windows. Upon completion of the data entry, frequencies generated from SPSS were checked for accuracy of data entry and missing data or out of range responses. The researcher found only 365 questionnaire responses were usable because 15 of the respondents did not answer all the questions. Based on the general principles when dealing with missing data, the researcher can deal with the missing data by analysing the available data; imputing the missing data with replacement values; imputing the missing data and accounting for the fact that these were imputed with uncertainty or using statistical models to allow for missing data. After much consideration, the researcher decided to only analyse the complete data (Pigott, 2001).

\section{Results}

As shown in Table 1, out of 365 respondents, 239 (65.5\%) are college students and 126 $(34.5 \%)$ are non-college students.

Table 1: Demographic of respondents

\begin{tabular}{|l|l|l|}
\hline Students & Frequency & Percentage (\%) \\
\hline College students & 239 & 65.5 \\
\hline Non-college students & 126 & 34.5 \\
\hline Total & 365 & 100.0 \\
\hline
\end{tabular}

All numerical data is described using mean. Table 2 shows the mean values of responses ranging between 2.61 to 3.40. Under "Influence of person to the choice of course study", the mean score for college students and non-college students is 3.40 for parents, friends (3.18 for college students and 3.15 for non-college students), counsellors (3.14 for college students and 3.02 for non-college students) and relatives (3.02 for college students and 2.83 for non-college students). The mean scores reflect that majority of the respondents "Agree" that parents are the most influential person in regards to the course of study.

The highest mean score for "Major influence to the choice of college/university" is parents which is 3.39 for college students and 3.47 for non-college students. Both college and non-college students agree that parents are the most influential people in regards to the choice of college or university for their future studies. As for friends, the mean score is 3.18 for college and non-college students respectively. Counsellors score 3.15 for college students and 3.11 for non-college students. 
For "Considered criteria to the choice of college/university", the mean score is 3.51 for industry trained lecturers for college students and 3.31 for non-college students. Non-college students score higher on affiliation with universities abroad with the mean score of 3.40. Reputation of the college or university has the second highest mean score of 3.49 and 3.35 for college and non-college students. History of top graduates has a mean score of 3.38 (college student) and 3.33 (non-college students). The lowest mean score is "A social playground on campus" which is 3.26 and 3.29, respectively. Both college and non-college students do not regard the college and university as a place for them to socialise. College students consider industry trained lecturers as an important criteria when choosing their choice of college or university but non-college students think that affiliation with universities abroad is more important.

As for the reason for going to college or university, the reason "To realise own dreams" has the highest mean score for college students at 3.71 and 3.70 for non-college students compared to other reasons, which included "To discover new interests, talents and experience", at 3.66 (college students) and 3.65 (non-college students). As for the reason of "Going to college or university is to realise parents' dreams" the percentage is 2.91 (college students) and 3.02 (non-college students). "Everyone does it" has the lowest mean score of 2.79 and 2.83 , respectively. It is obvious the reason to further studies for college and non-college students is to make their own dreams come true.

Table 2: Mean for the sources in the study

\begin{tabular}{|c|c|c|c|}
\hline & & $M$ & $M$ \\
\hline & & College students & Non-college students \\
\hline \multirow{4}{*}{$\begin{array}{l}\text { Influential person to the choice of } \\
\text { course of study }\end{array}$} & Parents & 3.40 & 3.40 \\
\hline & Friends & 3.18 & 3.15 \\
\hline & Relatives & 3.02 & 2.83 \\
\hline & Counsellors & 3.14 & 3.02 \\
\hline \multirow{4}{*}{$\begin{array}{c}\text { Major influence to the choice of } \\
\text { college/university }\end{array}$} & Parents & 3.39 & 3.47 \\
\hline & Friends & 3.18 & 3.18 \\
\hline & Relatives & 2.97 & 2.94 \\
\hline & Counsellors & 3.15 & 3.11 \\
\hline \multirow{5}{*}{$\begin{array}{l}\text { Considered criteria to the choice of } \\
\text { college/university }\end{array}$} & Reputation & 3.49 & 3.35 \\
\hline & $\begin{array}{r}\text { Affiliation with universi- } \\
\text { ties abroad }\end{array}$ & 3.48 & 3.40 \\
\hline & History of top graduates & 3.38 & 3.33 \\
\hline & $\begin{array}{r}\text { A social playground on } \\
\text { campus }\end{array}$ & 3.26 & 3.29 \\
\hline & Industry trained lecturers & 3.51 & 3.31 \\
\hline \multirow{4}{*}{$\begin{array}{l}\text { Reasons for going to col- } \\
\text { lege/university }\end{array}$} & Realise parents' dreams & 2.91 & 3.02 \\
\hline & Realise own dreams & 3.71 & 3.70 \\
\hline & $\begin{array}{l}\text { Discover new interests, } \\
\text { talents and experiences }\end{array}$ & 3.66 & 3.65 \\
\hline & Everyone does it & 2.79 & 2.83 \\
\hline \multirow{3}{*}{$\begin{array}{l}\text { Concerns when going to col- } \\
\text { lege/university }\end{array}$} & Not making new friends & 2.89 & 2.79 \\
\hline & $\begin{array}{r}\text { Exposed to negative ha- } \\
\text { bits }\end{array}$ & 2.69 & 2.61 \\
\hline & $\begin{array}{l}\text { Difficult to cope with } \\
\text { college/university life }\end{array}$ & 3.09 & 3.12 \\
\hline
\end{tabular}


The final question is about the concerns of students when going to college or university. From the mean score, the reason of "Difficult to cope with college or university life" is the highest for college students and non-college students at 3.09 and 3.12 respectively. "Not making new friends" has the mean core of 2.89 for college students, 2.79 for non-college students and "Afraid to expose themselves to negative habits" displays the lowest mean score of 2.69 and 2.61. Therefore, the major concern for college and non-college students is the difficulty to cope with college or university life.

\section{Discussion}

The summary of the descriptive statistics shows that college students and non-college students who were involved in this study agreed that parents are the most influential or important person when choosing their choice of college or university and course of study. One of the possible reasons is students perceive parents as their main source of finance. It is expected that parents pay for their children's education because most students do not have the ability to finance their studies, though some students choose to do part-time work to help fund their studies (Shumba and Naong, 2012). From an Asian perspective, the influence of parents plays a major role in students' choice of college and course of study. Students would normally seek advice from their parents before making their final decisions due to the perception that parents have the relevant information or experience with regards to higher education, and hence, parents are viewed as a credible source of advice (Westbrook and Scott, 2012).

In choosing a college or university for one's tertiary education, some of the criteria would probably be the type of academic programmes offered, college expenses, college environment, facilities, financial aids and a host of other factors. From this study, one of the most important criteria for non- college students is the affiliation with universities abroad. Non-college students are more interested in attending colleges which are affiliated with overseas universities compared to college students who view having industry trained lecturers as a much more important criteria. It is likely that college students may not only want to be "book smart" but to be also "street smart." A degree may help open doors to better job opportunities, but being "street smart" allows graduates to be more successful in their careers and personal lives. Furthermore, learning from industry trained lecturers enable college students to find out more about the real working environment, which one cannot find out from textbooks alone. Thus, industry trained lecturers can better inform and educate students on what goes on in workplaces and how they can survive in a highly competitive work environment.

On top of that, a majority of college and non-college students have the perception that they have to further their studies in order to make their dreams come true. Nowadays, a degree is an investment for one's future. A student may perceive that his or her future interests can be accomplished with a certification from a higher institution. However, the main concern in going to colleges or universities is in coping with the challenges faced in these educational institutions. Students often find it difficult at times, especially during the first year in a college or university. Everything is different and there is the new environment to get accustomed to. Adapting to a lot of changes all at once can sometimes be stressful for first year students. 
Educational marketers should utilise the findings of the study to come up with appropriate marketing strategies to promote their products and services.

\section{Limitations of the study}

As with any study, this study has several limitations. The first limitation was the instrument created by the researcher, which was not piloted before being administered to the participants of the study. Therefore, no reliability statistics were available. It is possible that the instrument would not accurately measure the influence of "factors" on the student choices in choosing colleges or universities and their course of study. Hence, the result of the study could not be generalised to the entire population. In addition, the design of questionnaire might lead to insufficient questions and as a result, lead to little depth. Another limitation related to the study is the sampling method employed. Convenience sampling is a non-probability sampling which has received criticisms from researchers as not being accurate and representative of the entire population. Furthermore, some of the surveys were done through the web. Although extreme care has being taken, a strong element of subjectivity is still present.

Additional limitation to the study is the lack of conceptual framework. There is no theory or concept to form the foundation of the study. No variables were indicated in the study. Hence, this study could only be considered as a poll to identify the "factors" influencing student choices of choosing college or university and course of study in Penang. Hence, the interpretations of the study are rather limited.

\section{Conclusion}

In conclusion, this study is to explore Malaysia's education scene, especially from the viewpoint of students. Clearly, parents are the most influential person in students' choices of colleges and universities, and course of study. Further research into the role of traditional givers of information, that is high school counsellors, would be beneficial. This source was rated by a majority of students as less important compared to parents and friends. This apparent ineffectiveness could be attributed to the method of delivery of information to students. Another area of concern is the reputation of college or university which was also rated as a less important criterion in the study. Above all, due to the various limitations to the current study, educational marketers and administrators should conduct follow-up studies to provide more coverage relative to the findings of this study.

\section{References}

Berenson, M.L., Levine, D.M. and Krehbiel, T.C. (2006), Basic Business Statistics, Prentice Hall, New Jersey.

Crozier, G. (1999), "Parental involvement: Who wants it?", International Studies in Sociology of Education, Vol.9 No.3, pp. 219-238.

Pigott, T.D. (2001), "A review of methods for missing data", Education Research and Evaluation, Vol.7 No. pp. 353-383.

Samsinar Md. Sidin., Siti Rahayu Hussin. and Tan, S.H. (2003), "An exploratory study of factors influencing the college choice decision of undergraduate students in Malaysia" Asia Pacific Management Review, Vol.8 No. 3, pp. 259-280. 
Shumba, A. and Naong, M. (2012), "Factors influencing Students' career choice and aspiration in South Africa" J Soc Sci, Vol.33, No. pp. 169-178.

Wan Chang Da. (2007), "Public and private higher education institutions in Malaysia: Competing, complementary or crossbreeds as education providers", Kajian Malaysia, Jld. XXV, No. 1, pp. 1-14.

Westbrook, S.B. and Scott, J.A. (2012), "The influence of parents on the persistence decisions of first-generation college students", Focus on Colleges, Universities, and Schools, Vol.6 No. 1, pp. 1-9. 